\title{
Suspected hereditary cervicothoracic vertebral subluxation with cervical myopathy in Poll Merino sheep
}

N Cronin, ${ }^{a^{*}}$ P Loukopoulos, ${ }^{b, c}$ D Brown, ${ }^{d}$ BA O'Rourke, ${ }^{e}$ G Morrice ${ }^{f, g}$ and PA Windsor $^{\text {h }}$

${ }^{*}$ Corresponding author

${ }^{a}$ Central West Local Land Services, 46 Sherriff Street, Forbes, NSW, 2871, Australia; nik.cronin@lls.nsw.gov.au

${ }^{\mathrm{b}}$ School of Animal and Veterinary Sciences, Charles Sturt University, Albert Pugsley Place, Wagga Wagga, NSW, 2650, Australia

c Melbourne Veterinary School, Faculty of Agricultural and Veterinary Sciences, 250 Princes Highway, Werribee, Victoria, 3030, Australia (Current institution)

${ }^{\mathrm{d}}$ Animal Genetics and Breeding Unit, University of New England, Armidale, NSW 2351, Australia

e New South Wales Department of Primary Industries, Elizabeth Macarthur Agricultural Institute, Menangle, NSW, 2568, Australia

${ }^{f}$ Riverina Local Land Services, 8 Bolton Street, Narrandera, NSW, 2700,

Australia

${ }^{9}$ Private consultant (Current)

${ }^{\mathrm{h}}$ The University of Sydney, Sydney School of Veterinary Science, Camden, NSW, 2570, Australia

\section{Abstract}

This is the author manuscript accepted for publication and has undergone full peer review but has not been through the copyediting, typesetting, pagination and proofreading process, which may lead to differences between this version and the Version of Record. Please cite this article as doi: $10.1111 /$ avj.12877

This article is protected by copyright. All rights reserved. 


\section{Case Report}

A New South Wales sheep producer reported a postural and locomotor disorder with a low prevalence in his poll merino stud flock, affecting neonate, weaner and adult sheep. Animals with postural abnormalities, variable degrees of ataxia, and proprioceptive deficits involving both fore and hind limbs were described. Abnormalities of the cervicothoracic vertebral column were identified grossly during necropsy, with misalignment and consequent narrowing of the posterior cervical spinal canal. Lesions ranging from pallor (cellular degeneration) to white streaky lesions with pin point haemorrhage (necrosis) were identified in the cervicothoracic paravertebral musculature of affected animals. Boney abnormalities were further characterised by imaging studies. Pedigree analysis of the very extensive breeding and disease incident records available for this flock suggested the disease was inherited. A similar case recognised in a separate New South Wales poll merino flock is also described.

\section{Conclusion}

This report describes an entity of cervicothoracic vertebral subluxation in two Poll Merino sheep flocks, with cervical myopathy also identified in one, with preliminary evidence in the primary case that there is likely to be a hereditary basis. The two cases outlined in this report resemble the findings of several historical investigations into ovine flock postural disorders in Australia, and beyond. 
Keywords cervical myopathy; cervicothoracic vertebral subluxation; hereditary; ataxia; sheep; Merino

\section{Introduction}

Cervicothoracic vertebral subluxation in sheep is an entity that has been presented in two previous case reports in this journal ${ }^{1,2}$. Concurrent cervical myopathy was also recognised in one of these ${ }^{2}$. In a paper reviewing disorders of the central nervous system in Australian Merino sheep that are known, or strongly suspected to be inherited ${ }^{3}$, these two reports were excluded as it was considered there was insufficient evidence to incriminate genetic factors. In this paper, evidence is presented that at least one occurrence of cervicothoracic vertebral subluxation may have a hereditary basis. The findings of several historical investigations into ovine flock postural disorders in Australia, and beyond are also discussed.

\section{Case report}

In 2014, a Poll Merino stud owner reported to a District Veterinarian with the Central West Local Land Services, New South Wales, that he had noticed a small number of his young sheep develop 'difficulty in walking' during the previous 16 years. They presented with low hanging heads and a 'scuttling' gait. The affected sheep had varying degrees of ataxia and paresis, and exercise intolerance and an associated respiratory stridor were identified at mustering. The owner had extensive historical records of the flock, and the number of affected animals had 
increased from 0, 1 or 2 animals between 2000 and 2006, to between 3 and 20 animals from 2007 to 2014 . Affected animals were both male and female. Most developed clinical signs post weaning, although more recently some animals developed signs in adulthood. In the past five years the owner observed a small number (ranging 1-4) of cases affected as newborn lambs. In general, the severity of clinical signs increased over a variable number of months, leading to a loss of body condition from inappetance, and death, or culling from the mob. However, a small number of affected ewes survived to join and produce an apparently normal lamb.

\section{I nitial investigations of seven sheep}

The property was visited in 2015 to examine 7 affected ewes - three weaners, two hoggets and two that were 5 years old. These animals displayed similar signs, characterised by an abnormal posture, with a wide based stance and low hanging head. When driven, they showed variable degrees of ataxia and proprioceptive deficits affecting fore and hindlimbs (Supplementary file).

An affected weaner and hogget were selected for euthanasia and post mortem examination. At necropsy, there was apparent misalignment of part of the cervicothoracic vertebral column, with 'upward' deviation at the C7-T1 region and consequent narrowing of the posterior cervical spinal canal.

Brain, cervical and thoracic spinal cord, heart, lung, liver and kidney tissues from the ewe, and cervical spinal cord from the weaner were collected and fixed in $10 \%$ neutral buffered formalin. The abnormal section of cervicothoracic vertebral 
column from both sheep was also collected. Necropsy samples were submitted to the Elizabeth Macarthur Agricultural Institute, Menangle, New South Wales.

Histopathological examination of the cervical spinal cord and nerve root tissue samples of both animals revealed mild to moderate Wallerian degeneration characterised by vacuolation of the ventromedial and ventrolateral white matter, with degenerate macrophages or axonal debris in some vacuoles. In transverse tissue sections it was noted that the Wallerian degeneration was mild to moderate in the ventral and lateral white matter, and very mild in the dorsal white matter. No lesions suggestive of a Transmissable Spongiform Encephalopathy were identified in the hogget, and no significant lesions were found in other tissues submitted. Sectioning of the vertebral column demonstrated the deviation and narrowing of the spinal canal between $\mathrm{C} 7$ and T1 (Figure 1). The findings were consistent with two previous reports of ovine cervicothoracic vertebral subluxation. ${ }^{1,2}$

\section{Investigation of a neonatal lamb}

The property was visited during the next lambing to examine a neonatal ewe lamb identified by the producer as being affected (Figure 2). It weighed approximately $2.5 \mathrm{~kg}$, and carried its head low on a straightened neck. It displayed a wide-based stance with slightly sloping hindquarters and moved with a mildly hypometric shuffling gait. There was no pain response elicited on palpation of the neck and shoulder region, or flexion and extension of the neck. 
Blood was collected from the jugular vein before the animal was euthanased for post mortem examination.

At necropsy, lesions appearing as segmental white streaks with mild pinpoint haemorrhages were observed bilaterally in several cervicothoracic paravertebral muscles, including, but not limited to, the longissimus and spinalis muscle groups (Figure 3). A range of skeletal muscle sections from left and right cervicothoracic regions were collected and fixed in $10 \%$ neutral buffered formalin. Cardiac muscle, liver, kidney and spleen tissues were also collected and fixed. The intact vertebral column (spinal cord not removed) was dissected from the carcase and frozen for storage. Necropsy samples were submitted to the Charles Sturt University Veterinary Diagnostic Laboratory, Wagga Wagga, New South Wales.

Histopathological examination of the cervicothoracic skeletal muscle tissues identified skeletal muscle degeneration and necrosis, bilaterally, in all tissues examined. The degree of severity varied from mild to exceedingly severe. Degeneration and necrosis of individual myocytes exhibited as fragmentation, cytoplasmic swelling, marked vacuolation, cytoplasmic hypereosinophilia and hyalinisation, and loss of striation. There was also multifocal mineralisation and attempts at regeneration, and a single focus each of haemorrhage and mild oedema. Attempts at regeneration were evident with the presence of internalised nuclei in some cells (rowing), numerous mitotic figures and proliferation of satellite cells (satellitosis) and fibroblasts, as well as multifocal 
collagen deposition (fibrosis). In many sections, changes were severe enough to completely obliterate muscle architecture (Figure 4). No significant lesions were found in other tissues submitted.

Whole blood glutathione peroxidase activities, as a measure of blood Se concentration, were within the normal range $(464 \mathrm{U} / \mathrm{gHb}$, range $50-550)$, thus excluding a nutritional myopathy. The sample quantity was insufficient for Vitamin E level testing.

\section{Investigation of three additional cases, with diagnostic imaging}

Three clinically affected adult ewes were presented to the Charles Sturt University Veterinary Diagnostic Laboratory for investigation. They were in good condition, despite showing clinical signs of neck weakness with low hanging heads, and variable degrees of hindlimb ataxia. Following clinical examination, blood was collected from the jugular vein before euthanasia.

At necropsy, subtle lesions of segmental areas of pallor were seen bilaterally in the cervicothoracic paravertebral musculature of the three sheep, at sites similar to where lesions were identified in the neonatal lamb. A range of skeletal muscle sections from left and right cervicothoracic regions were collected and fixed in $10 \%$ neutral buffered formalin. Other tissues also collected and fixed included brain, spinal cord, diaphragm, lung, lymph node, pancreas, small and large intestine, rumen, reticulum and kidney. The intact vertebral columns were dissected from the carcases and stored frozen for imaging. 
Histopathologically, the lesions in the cervicothoracic skeletal muscle sections were of varying severity but similar in nature in the three sheep and consisted of moderate to severe atrophy, degeneration and regeneration with marked fatty infiltration (Figure 5). There was marked myofibroblast aggregation at sites of myofibre degeneration and marked rowing, and few small foci of lymphoplasmacytic aggregation. No lesions were identified in the spinal cord sections reviewed. No significant related lesions were found in other tissues submitted.

The vertebral columns of these three sheep and the neonatal lamb were submitted for radiographic and computed tomography scan examination at the Charles Sturt University School of Animal and Veterinary Sciences, Wagga Wagga, New South Wales. This study showed moderate to severe kyphosis and scoliosis, with severe, focally extensive malformation of several cervicothoracic vertebrae and the corresponding articular surfaces. It also demonstrated the narrowing of the cervicothoracic segment of the spinal canal of the adult sheep (Figure 6) and the neonate. The 'wedging' deformity of T1 as previously described in other cases of cervicothoracic vertebral subluxation ${ }^{1,2,4,5}$ was also present.

\section{Pedigree Analysis}

The breeder had an extensive database of pedigree information and performance records spanning over 30 years, and in recent years had identified the affected animals. The oldest record of an affected animal was born in 1998, and in total, 
64 animals were recorded as being affected out of a population of approximately 23,000 born over the same period. This data was examined by researchers at the Animal Genetics Breeding Unit, University of New England, Armidale, New South Wales. Affected animals were traced through the pedigree and estimates of the probabilities of each animal producing an affected progeny supported a genetic basis for the disorder with a recessive mode of inheritance. Further investigation of the pedigree suggested that nearly 300 animals in the pedigree could be carriers. There were 5 key sires having over 10 progeny in the pedigree of the affected animals. The researchers acknowledged that collation of further data would allow a more detailed genetic analysis and potential mode of inheritance to be produced. More accurate phenotyping of the trait would also help better understand the influence of genetics in the expression of the disorder.

\section{Likely occurrence in a second Poll Merino flock}

In 2015, the District Veterinarian from the Riverina Local Land Services, New South Wales reported a disease investigation in a self-replacing Poll Merino flock in which cervicothoracic vertebral subluxation was also diagnosed. There was a similar history and clinical presentation to the current case and those previously reported. ${ }^{1,2}$ The producer on this property had run the same bloodline of sheep for 30 years, and had noticed a small number (approximately $1 \%$ ewe lambs) of affected animals for the past 5 years. Most cases were observed to occur from 12 months of age and become progressively worse if left in the mob. The animals exhibited a 'dropped neck', with a wide-based stance, dysmetria, and 
reduced proprioception in forelimbs. Dyspnoea when pushed was also described, similar to the respiratory stridor described by the owner in the original case. Post mortem examination with sectioning of the spinal cord indicated compression in the cervicothoracic spinal cord, with histopathology of the spinal cord sections revealing mild multifocal Wallerian degeneration within the ventral spinal tracts. The bloodline of this flock and the stud in the original investigation was not known to be linked.

\section{Molecular studies}

The preliminary pedigree analysis was supportive of the hypothesis that this disorder was inherited. A study of the possible molecular basis of the disease has been initiated at the Elizabeth Macarthur Agricultural Institute in collaboration with The University of Sydney. Samples and data from affected Merino sheep on both reported properties were collected for nucleic acid extraction, with homozygosity mapping used to identify candidate chromosomal locations. Preliminary work has mapped the disease causing mutation. Current investigations, including analysis of whole genome sequencing data, are expected to identify the disease causing mutation and enable heterozygote detection. $^{6}$

\section{Discussion}

When considering potential causes in the primary case presented we were extremely fortunate to have a very comprehensive flock database to explore the 
possibility that the disease might have a hereditary basis. The producer had recognised these animals within his flock for 15 years (at the time of reporting) and had been identifying them as 'affected' within his modelling system. This pedigree data then enabled the preliminary genetic analysis which has supported a hereditary basis for the disease. Likely carrier animals have been identified which will assist in on-farm breeding decisions to reduce and ultimately eliminate disease incidence within this flock. As the molecular studies advance, there is potential for development of a screening test to identify carriers to avoid at risk matings.

Cervicothoracic vertebral subluxation as a cause of ataxia has been previously described in Merino ${ }^{1}$ and Corriedale ${ }^{2}$ sheep in Australia, and Colombia lambs in California, USA ${ }^{4}$ and Suffolk lambs in Edinburgh, Scotland ${ }^{5}$, and the similarities and differences between these reports and our cases is summarised in Table 1.

This entity has been identified as a cause of disease in several sheep breeds around the world. Its prevalence within affected flocks varies from very low (culled $0.14 \%)^{1}$, up to $10 \%$ in one small breeding flock ${ }^{4}$. In three of the cases $^{2,4,5}$ affected animals are identified as neonates or young lambs. In two of the three cases in merino flocks ${ }^{1}$, the disease presented in older juvenile animals, either weaner to 12 months of age. This may in part reflect the more extensive style of management of these flocks, particularly in the report where the property was located in central western Queensland ${ }^{1}$. But in the primary case presented in our paper, while a number of animals were recognised 
affected as neonates, others were not noticed to display clinical signs until adulthood. On this property there is close monitoring of neonatal lambs with 'mothering up' to visually identify a ewe and her lamb, so it appears that some affected animals in this flock are born clinically normal.

Head and neck postural changes are a consistent clinical finding, with descriptions of affected stock including a 'dropped or weak neck' ' or being ' $U$ necked $^{1,2}$ in appearance. Ataxia and proprioceptive deficits were also consistently described in all cases. While respiratory stridor was noted as a frequent finding by the producers of both flocks described in this paper, it was mentioned only in one other reported case. ${ }^{4}$

In three of the six tabled cases, clinical signs of affected sheep were generally progressive, or they were culled. ${ }^{1}$ In one case, progression is not described, but it is noted that normal neck function never develops. ${ }^{4}$ In another case, the author reports that some affected animals had suddenly became tetraplegic. ${ }^{2}$ However, Nisbet and Renwick recorded 'spontaneous recovery' in the majority of their cases. ${ }^{5}$ It is assumed that this recovery relates to clinical signs, and the paper does not discuss how the associated pathology evolves in clinically recovered animals.

Cervical myopathy was not present in all tabled cases of cervicothoracic vertebral subluxation. In the primary case discussed in this paper, myopathy was clearly visible grossly in the neonate when assessing cervical paravertebral muscle pathology, but significantly less so in the older animals. It is possible 
that myopathy existed in other cases but either the target sites were not directly examined, or lesions were not clearly evident in animals with mild pathology.

The primary case presented in this paper is the only one to have substantial evidence to suggest a hereditary basis for disease, although the close familial nature of purebred affected animals presented by Lakritz et al ${ }^{4}$ provides circumstantial support in that case.

\section{Conclusion}

Cervicothoracic vertebral subluxation in sheep is an important differential to consider when investigating presentations of postural and locomotor disorders in merino and other sheep breeds in Australia. Cervical myopathy may also be present. While the gross lesions of subluxation should be reasonably apparent during necropsy examination, those of the myopathy may not.

In the primary case discussed in this paper, there is preliminary evidence that this disease has a hereditary basis.

\section{Acknowledgements}

The detailed flock records and critical observations of the sheep stud owner have enabled the depth of both this clinical investigation and the ongoing molecular study. Erica Bunker, Veterinary Pathologist with the New South Wales Department of Primary Industries is thanked for linking the initial investigation findings in this case to the previous reports of ovine cervicothoracic vertebral subluxation. The contributions of Dr P Mantis, Royal Veterinary College, United 
Kingdom for his comments on imaging, and Mark Murray, previously with the School of Animal and Veterinary Sciences, Charles Sturt University for his expertise and assistance with conducting the imaging study, and the final year Charles Sturt University veterinary science students for assistance with the necropsies and imaging study conducted at the Veterinary Diagnostic Laboratory in Wagga are also gratefully acknowledged.

\section{References}

1. Hill BD, O'Dempsey ND, Carlisle CH. Cervicothoracic vertebral subluxation causing ataxia in sheep. Aust Vet J 1993; 70: 156-157

2. Hartley WJ, Stevenson JMK, McCarthy PH. Cervicothoracic vertebral subluxation causing ataxia in sheep. Aust Vet J 1994;71:267-268

3. Windsor, PA, Kessell, AE, Finnie, JW. Review of neurological diseases of ruminant livestock in Australia. VI. Post-natal bovine, ovine and caprine neurogenetic disorders. Aust Vet J 201189:432-438

4. Lakritz J, Barr CB, George LW et al. Cervical and thoracic vertebral malformation ("Weak neck") in Columbia lambs. J Vet Int Med 1995; 9: 393-398

5. Nisbet DI and Renwick CC. Congenital myopathy in lambs. J Comp Path 1961; 71: 177-182

6. Tulloch RL, O'Rourke BA, Woolley SA. Homozygosity mapping in sheep affected by cervicothoracic vertebral subluxation: candidate gene identification and novel mutation investigation. http://www.woolwise.com/wp-content/uploads/2017/05/2016-Rachel-Tulluch-ConferencePaper.pdf 


\section{Figure legends}

Supplementary File - Supplementary video of three affected sheep displaying a low hanging head and wide-based stance. When driven the affected animals show variable degrees of ataxia affecting fore and hindlimbs.

Figure 1 - Image of the sectioned vertebral column (C6, C7 and part T1) of the affected ewe displaying the 'upward' deviation at the C7-T1 region (arrow) and subsequent narrowing of the spinal canal.

Figure 2 - Image of an affected newborn lamb displaying a characteristic stance, with a low hanging head and wide-based forelimb stance.

Figure 3 - Image of the cervicothoracic paravertebral muscles of the neck in the affected neonatal lamb at necropsy, displaying white segmental lesions (arrow) indicative of cervical myopathy.

Figure 4 - Histological section of a segmental cervical muscle lesion of the affected neonatal lamb showing severe skeletal muscle degeneration and necrosis, marked myocyte fragmentation, multifocal mineralisation and marked fibrosis. Inset: higher magnification showing mineralisation foci, myocyte fragmentation, mitotic figures (regeneration), and internalisation of myofiber nuclei.

Figure 5 - Histological section of the cervical muscle lesion of an affected adult sheep showing showing replacement of myocytes by infiltrating adipocytes. 
Figure 6 - Computed tomography image of the cervicothoracic vertebral column

\author{
of an affected adult sheep showing severe malformation of several
}

cervicothoracic vertebrae, including 'wedging' of T1 (arrow).

\begin{tabular}{|c|c|c|c|c|c|c|}
\hline & $\begin{array}{c}\text { Cronin et al } \\
\text { (primary case) }\end{array}$ & $\begin{array}{c}\text { Cronin et al } \\
\text { (second case) }\end{array}$ & Hill et al 1 & Hartley et al 2 & Lakritz et al 4 & $\begin{array}{c}\text { Nisbet \& } \\
\text { Renwick* } 5\end{array}$ \\
\hline Breed & Merino & Merino & Merino & Corriedale & Colombia & Suffolk \\
\hline $\begin{array}{l}\text { Number } \\
\text { affected }\end{array}$ & Up to $1.5 \%$ & $\begin{array}{l}1 \% \text { ewe } \\
\text { progeny }\end{array}$ & $\begin{array}{c}\text { Not } \\
\text { established, } \\
\text { culled 0.14\% }\end{array}$ & Not noted & $\begin{array}{c}\text { Up to } \\
\text { approximately } \\
10 \%\end{array}$ & $\begin{array}{c}1.6-6 \% \text { progeny } \\
\text { over } 3 \text { years }\end{array}$ \\
\hline Age of onset & $\begin{array}{l}\text { Neonate to } \\
\text { young adult }\end{array}$ & $\begin{array}{l}\text { Most from } \\
12 \mathrm{mo}\end{array}$ & $\begin{array}{l}\text { At least } 6 \mathrm{mo} \text {, } \\
\text { mostly } 9-10 \mathrm{mo}\end{array}$ & Neonate & $\begin{array}{l}\text { Neonate, or } \\
\text { young lamb }\end{array}$ & Neonate \\
\hline $\begin{array}{l}\text { Head/neck } \\
\text { postural } \\
\text { change }\end{array}$ & $\begin{array}{c}\text { Yes, low/flat } \\
\text { hanging heads }\end{array}$ & $\begin{array}{c}\text { Yes, 'dropped } \\
\text { neck' }\end{array}$ & $\begin{array}{l}\text { Yes, shorter } \\
\text { than normal, } \\
\text { 'U-shape neck' }\end{array}$ & $\begin{array}{l}\text { Yes, unable to } \\
\text { lift head to } \\
\text { suckle at birth, } \\
\text { develop 'U- } \\
\text { necked' } \\
\text { appearance }\end{array}$ & $\begin{array}{l}\text { Yes, 'weak } \\
\text { neck' }\end{array}$ & $\begin{array}{l}\text { Yes, inability to } \\
\text { raise head to } \\
\text { normal position }\end{array}$ \\
\hline $\begin{array}{c}\text { Ataxia, } \\
\text { proprioceptive } \\
\text { deficits }\end{array}$ & $\begin{array}{l}\text { Yes, varying } \\
\text { degrees of }\end{array}$ & $\begin{array}{l}\text { Yes, dysmetria, } \\
\text { reduced } \\
\text { proprioception } \\
\text { in forelimbs }\end{array}$ & $\begin{array}{c}\text { Yes, mild to } \\
\text { severe } \\
\text { hindlimb ataxia }\end{array}$ & $\begin{array}{l}\text { Yes, posterior } \\
\text { inco-ordination }\end{array}$ & Yes & Not specified \\
\hline $\begin{array}{l}\text { Respiratory } \\
\text { stridor }\end{array}$ & $\begin{array}{l}\text { Yes, on } \\
\text { exertion }\end{array}$ & $\begin{array}{l}\text { Yes, on } \\
\text { exertion }\end{array}$ & Not specified & Not specified & $\begin{array}{c}\text { Yes, inspiratory } \\
\text { stridor }\end{array}$ & Not specified \\
\hline Pain & No & No & $\begin{array}{c}\text { Yes, } \\
\text { pronounced } \\
\text { neck rigidity, } \\
\text { resented } \\
\text { downward } \\
\text { flexion of the } \\
\text { neck }\end{array}$ & Not specified & $\begin{array}{l}\text { Yes, in some, } \\
\text { passive neck } \\
\text { movement } \\
\text { resulted in } \\
\text { vocalisation } \\
\text { and avoidance } \\
\text { responses }\end{array}$ & Not specified \\
\hline $\begin{array}{l}\text { Course of } \\
\text { disease }\end{array}$ & $\begin{array}{l}\text { Generally } \\
\text { progressive, } \\
\text { with thrift } \\
\text { leading to cull } \\
\text { or death }\end{array}$ & $\begin{array}{c}\text { Most } \\
\text { progressive }\end{array}$ & $\begin{array}{c}\text { Identified } \\
\text { animals culled }\end{array}$ & $\begin{array}{l}\text { Some animals } \\
\text { became } \\
\text { suddenly } \\
\text { tetraplegic }\end{array}$ & $\begin{array}{c}\text { Never } \\
\text { developed } \\
\text { normal neck } \\
\text { function }\end{array}$ & $\begin{array}{l}\text { Spontaneous } \\
\text { recovery within } \\
\text { months } \\
\text { (majority). Some } \\
\text { permanently } \\
\text { affected }\end{array}$ \\
\hline $\begin{array}{l}\text { Gross } \\
\text { findings }\end{array}$ & $\begin{array}{l}\text { Cervicothoracic } \\
\text { vertebral } \\
\text { subluxation, } \\
\text { cervical } \\
\text { myopathy }\end{array}$ & $\begin{array}{l}\text { Cervicothoracic } \\
\text { vertebral } \\
\text { subluxation, } \\
\text { spinal cord } \\
\text { compression }\end{array}$ & $\begin{array}{l}\text { Cervicothoracic } \\
\text { vertebral } \\
\text { subluxation }\end{array}$ & $\begin{array}{l}\text { Cervicothoracic } \\
\text { vertebral } \\
\text { subluxation, } \\
\text { spinal cord } \\
\text { compression, } \\
\text { cervical } \\
\text { myopathy }\end{array}$ & $\begin{array}{l}\text { Cervicothoracic } \\
\text { vertebral } \\
\text { subluxation }\end{array}$ & $\begin{array}{l}\text { Cervicothoracic } \\
\text { vertebral } \\
\text { subluxation, } \\
\text { spinal cord } \\
\text { compression, } \\
\text { cervical } \\
\text { myopathy }\end{array}$ \\
\hline $\begin{array}{l}\text { Evidence for } \\
\text { hereditary } \\
\text { aetiology }\end{array}$ & $\begin{array}{l}\text { Pedigree } \\
\text { analysis from } \\
\text { extensive farm } \\
\text { sheep } \\
\text { database }\end{array}$ & $\begin{array}{l}\text { Self replacing } \\
\text { flock }\end{array}$ & Not speculated & Not speculated & $\begin{array}{l}\text { Many affected } \\
\text { lambs were } \\
\text { related, all } \\
\text { were purebred } \\
\text { Colombia }\end{array}$ & Not speculated \\
\hline
\end{tabular}

Page | 16

This article is protected by copyright. All rights reserved. 


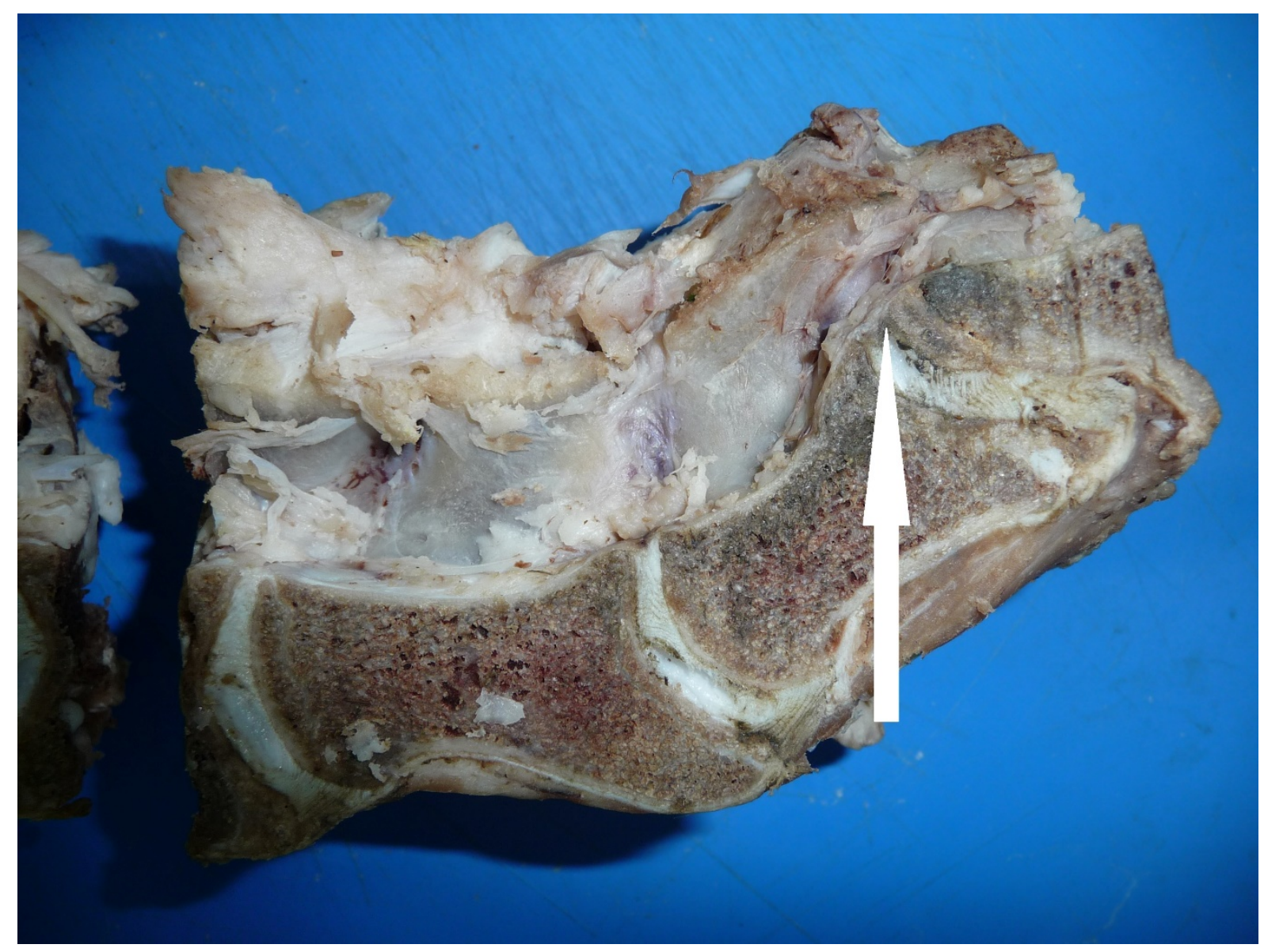

Page | 17

This article is protected by copyright. All rights reserved. 


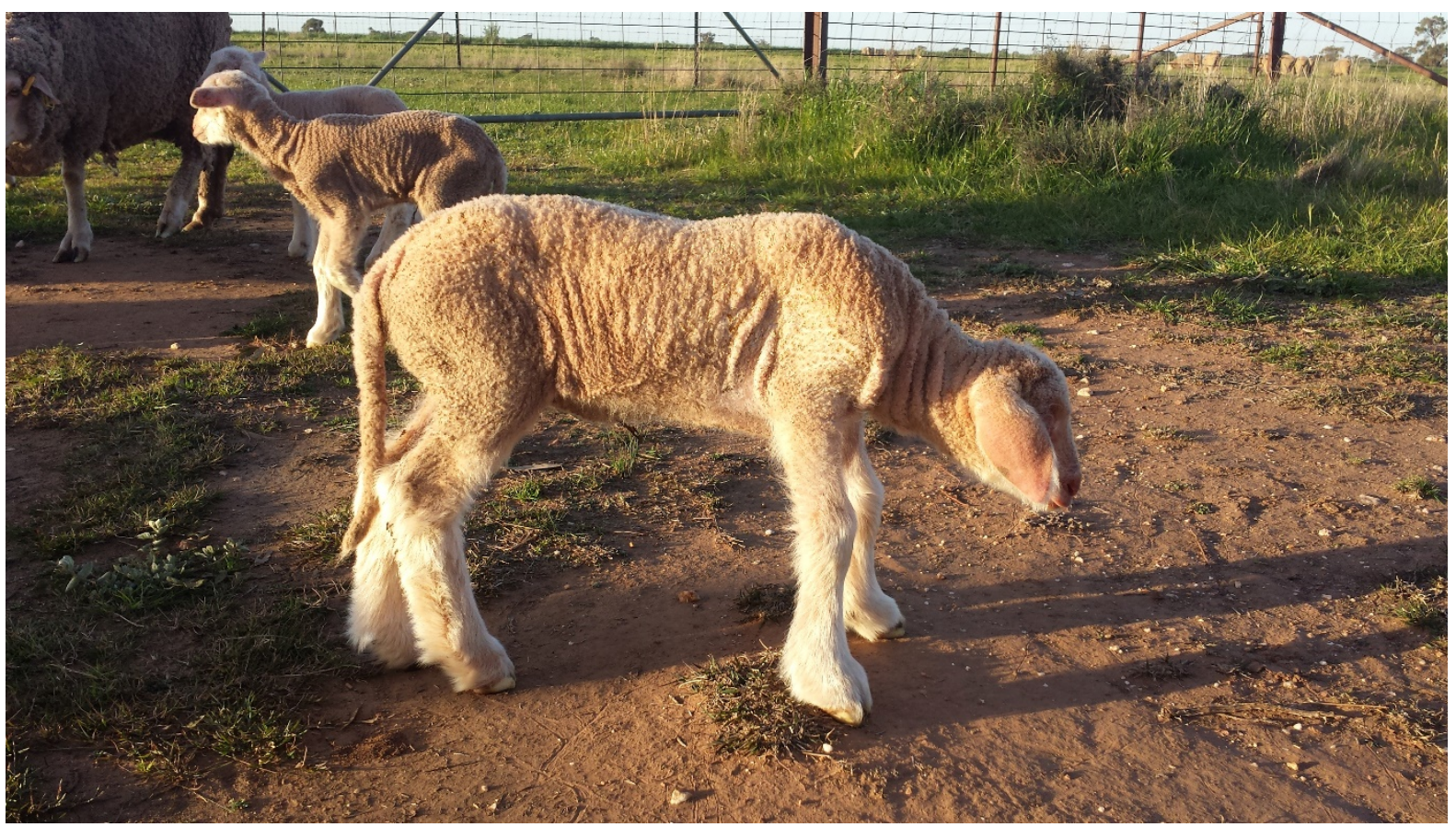

Page | 18

This article is protected by copyright. All rights reserved. 


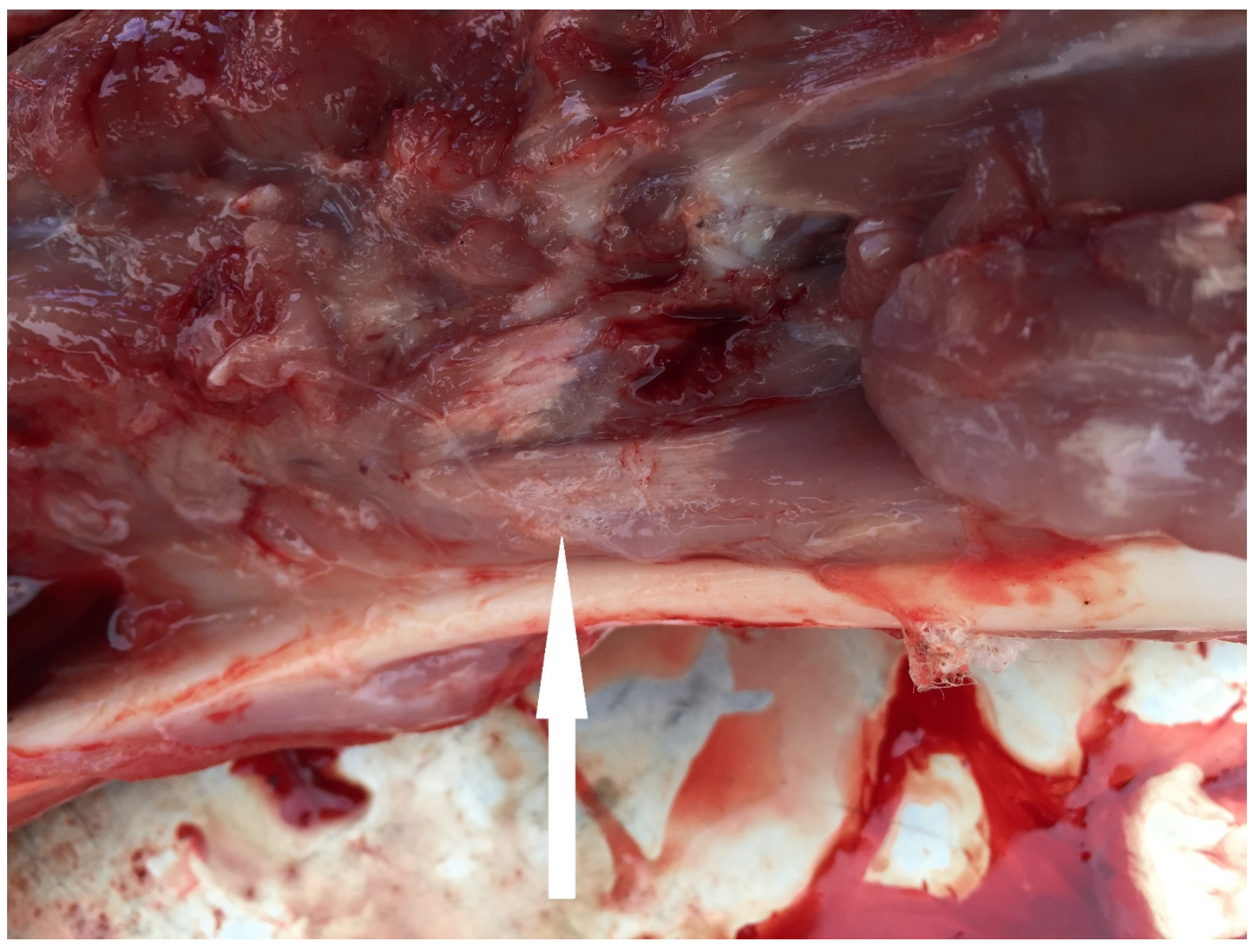

Page | 19

This article is protected by copyright. All rights reserved. 


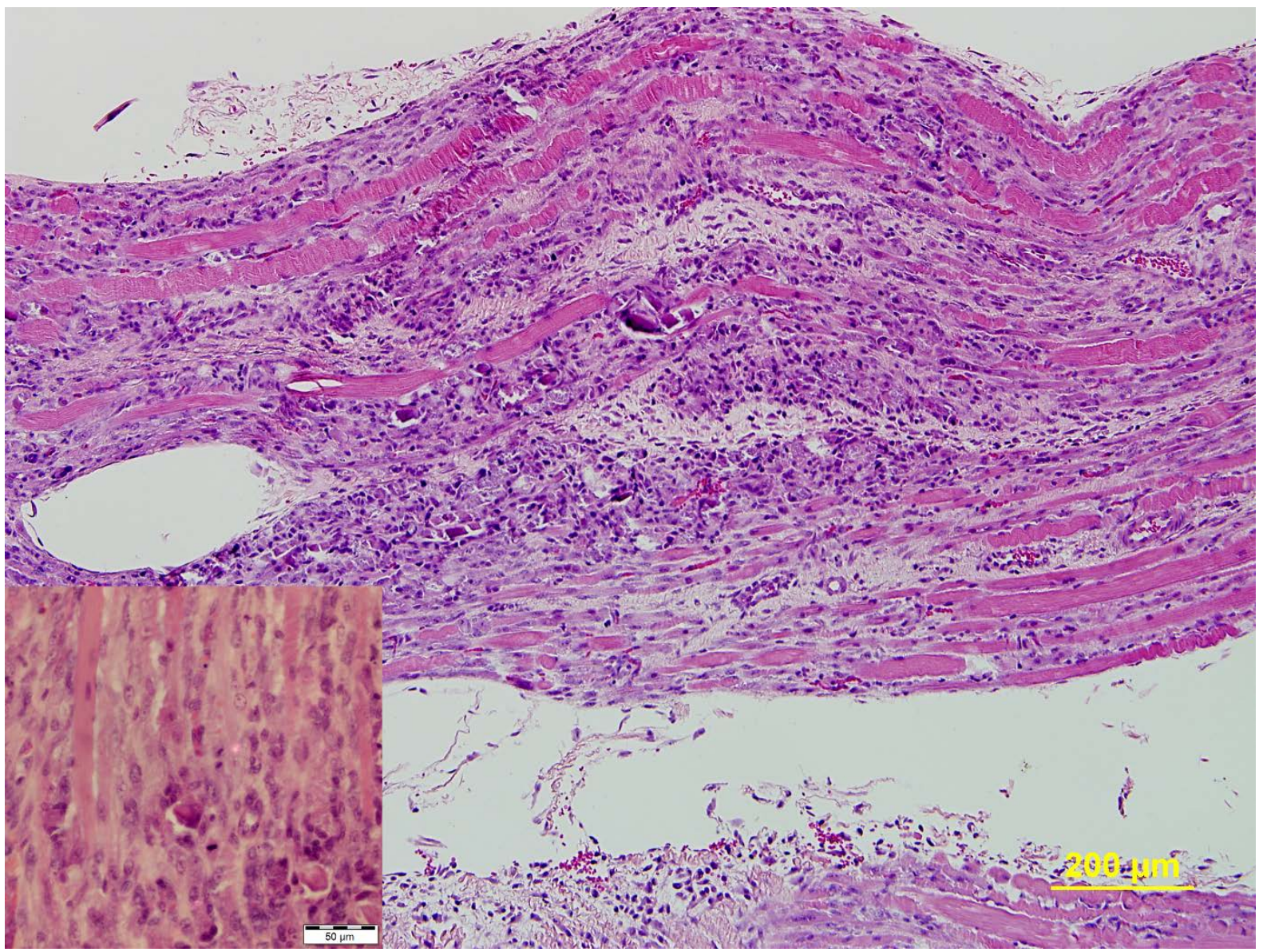

Page | 20

This article is protected by copyright. All rights reserved. 


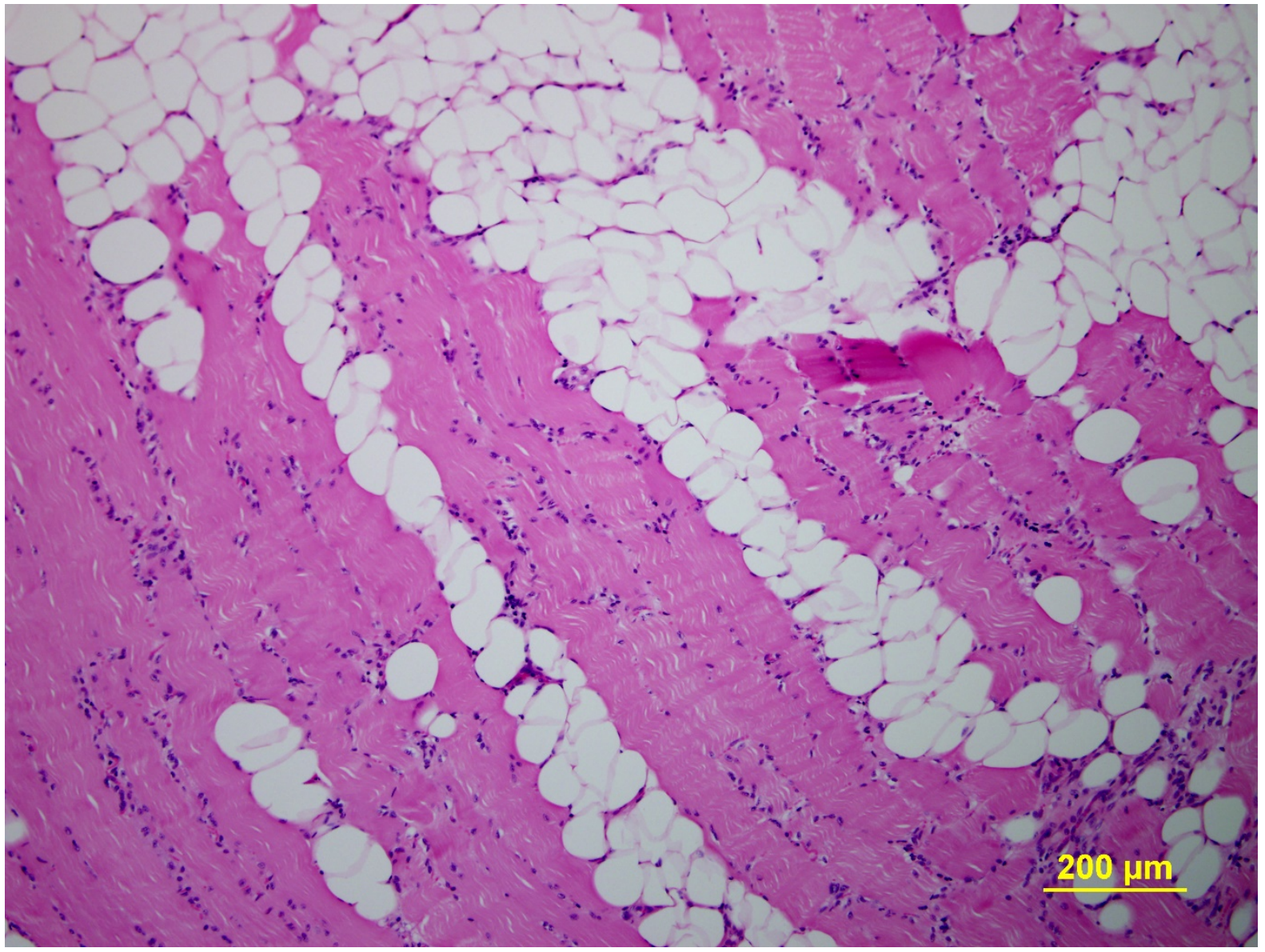

Page | 21

This article is protected by copyright. All rights reserved. 


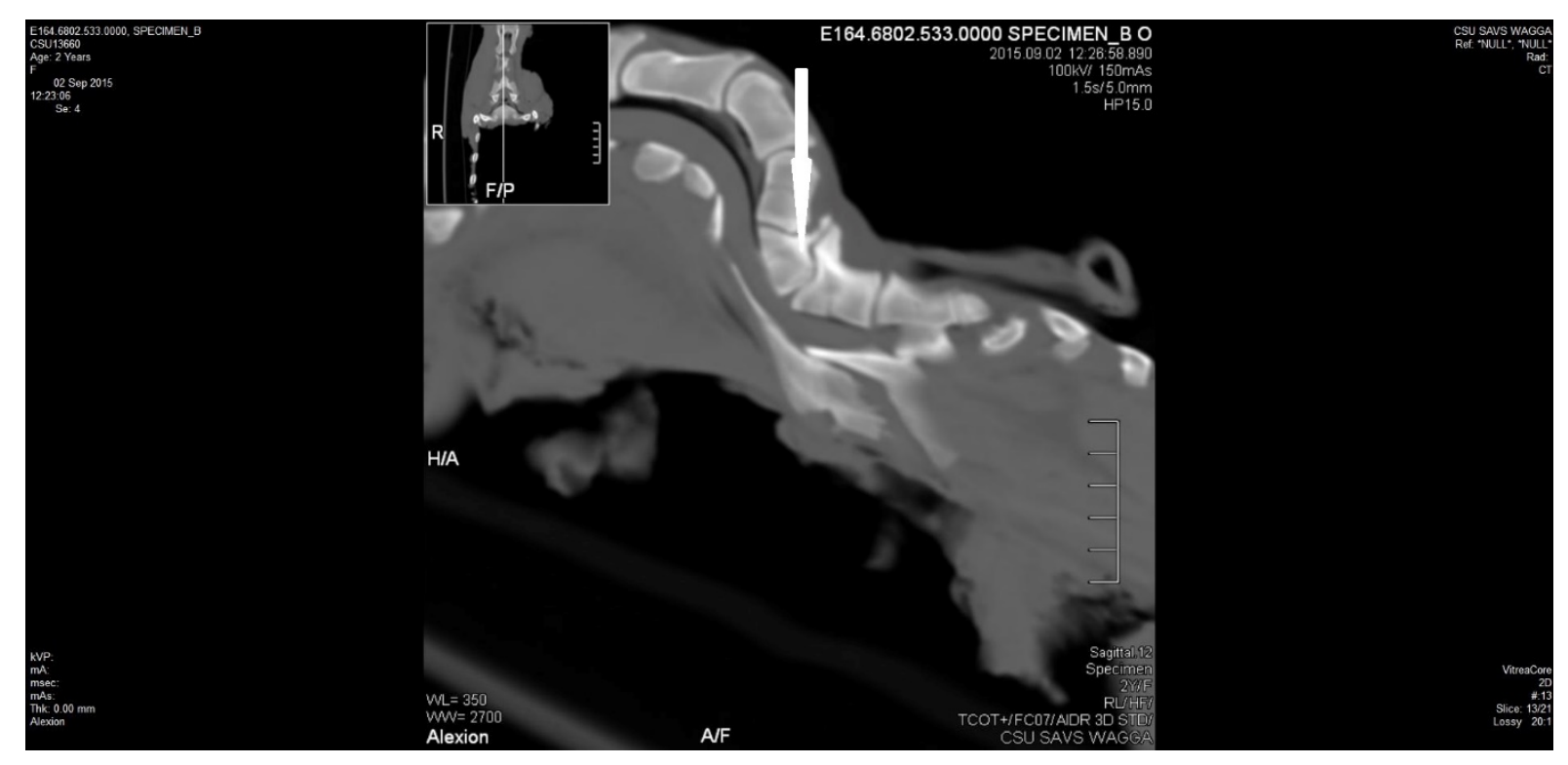

Page | 22

This article is protected by copyright. All rights reserved. 

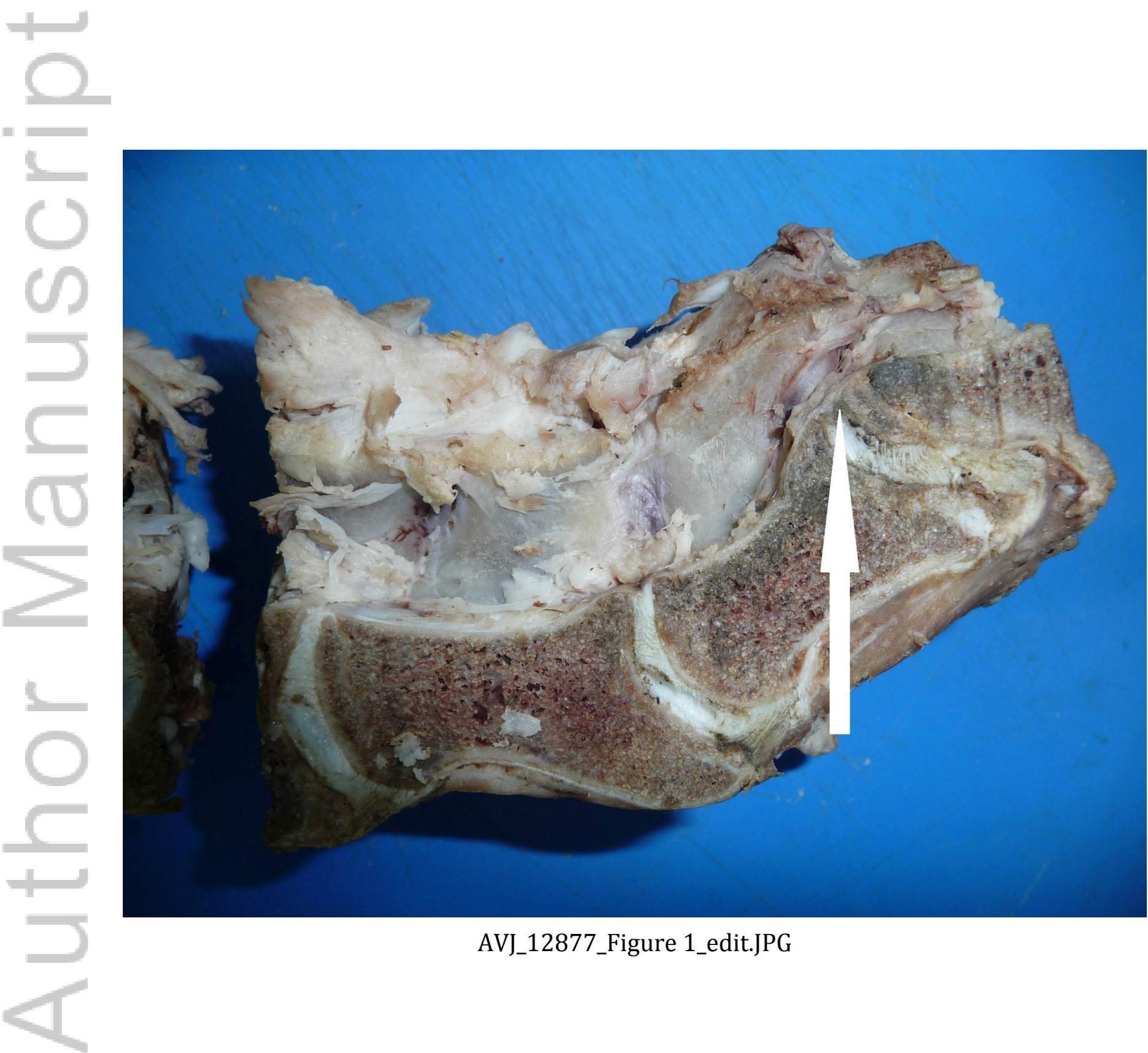

AVJ_12877_Figure 1_edit.JPG

This article is protected by copyright. All rights reserved. 


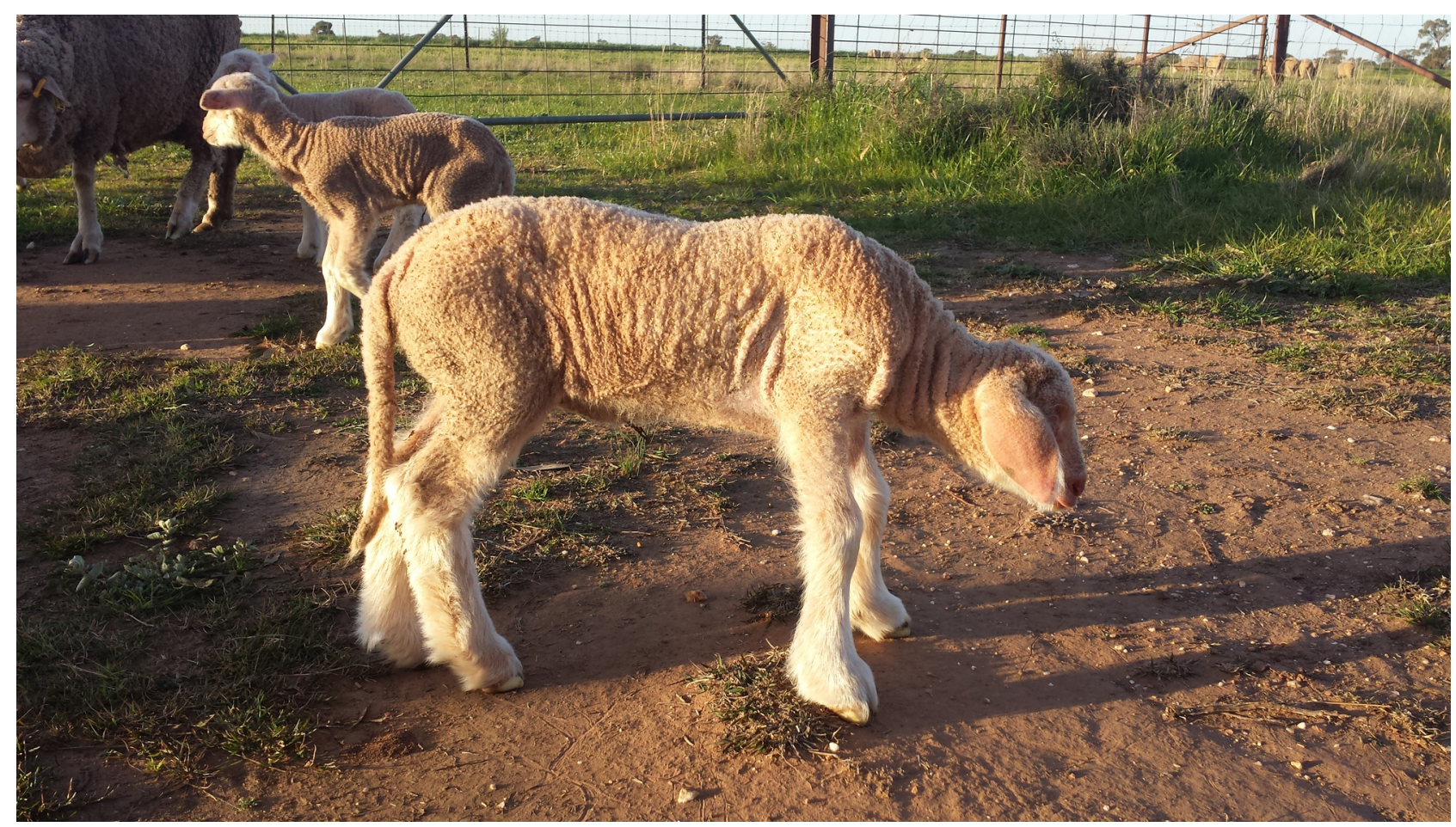

AVJ_12877_Figure 2_edit.jpg

This article is protected by copyright. All rights reserved. 

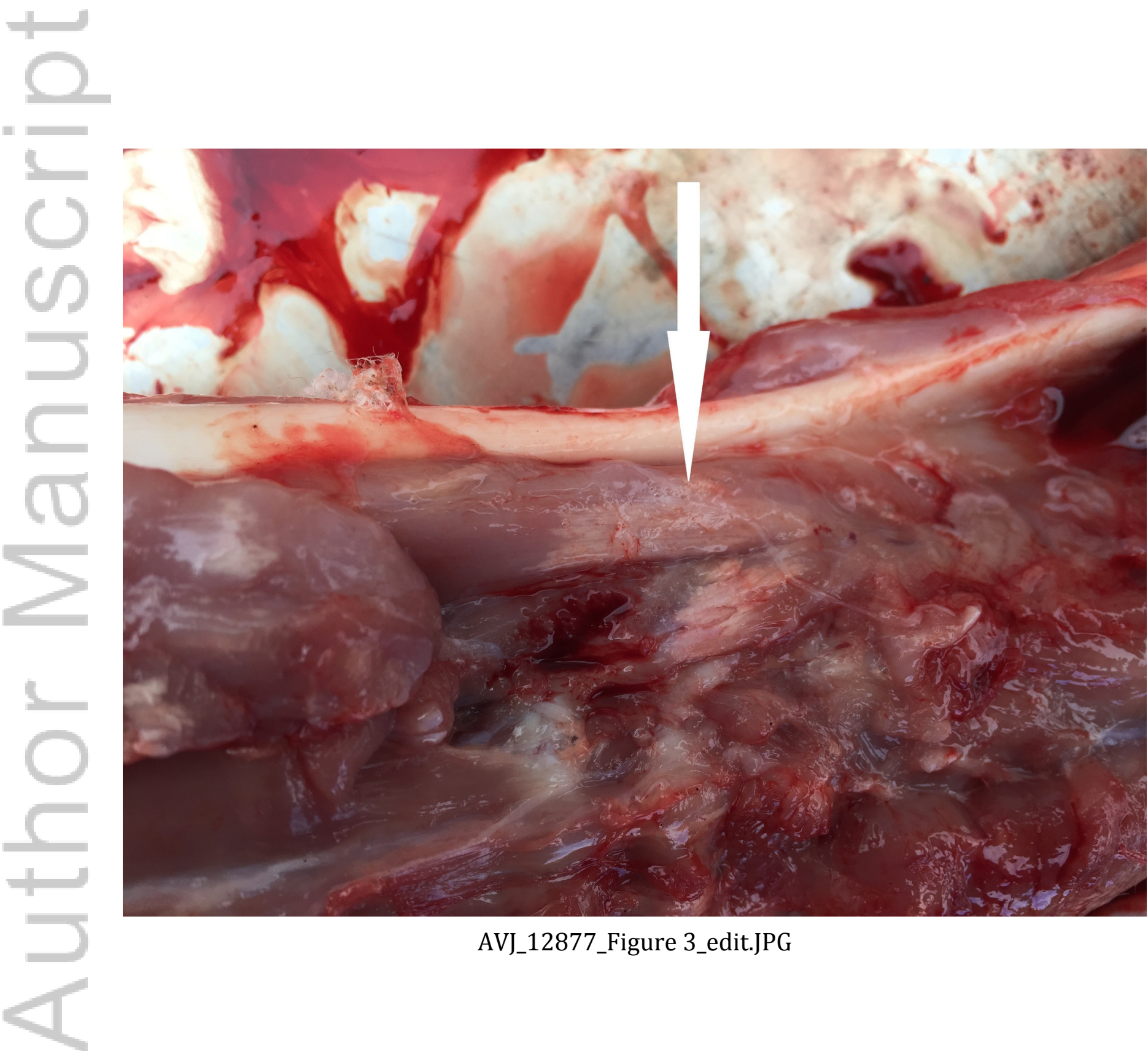

AVJ_12877_Figure 3_edit.JPG

This article is protected by copyright. All rights reserved. 


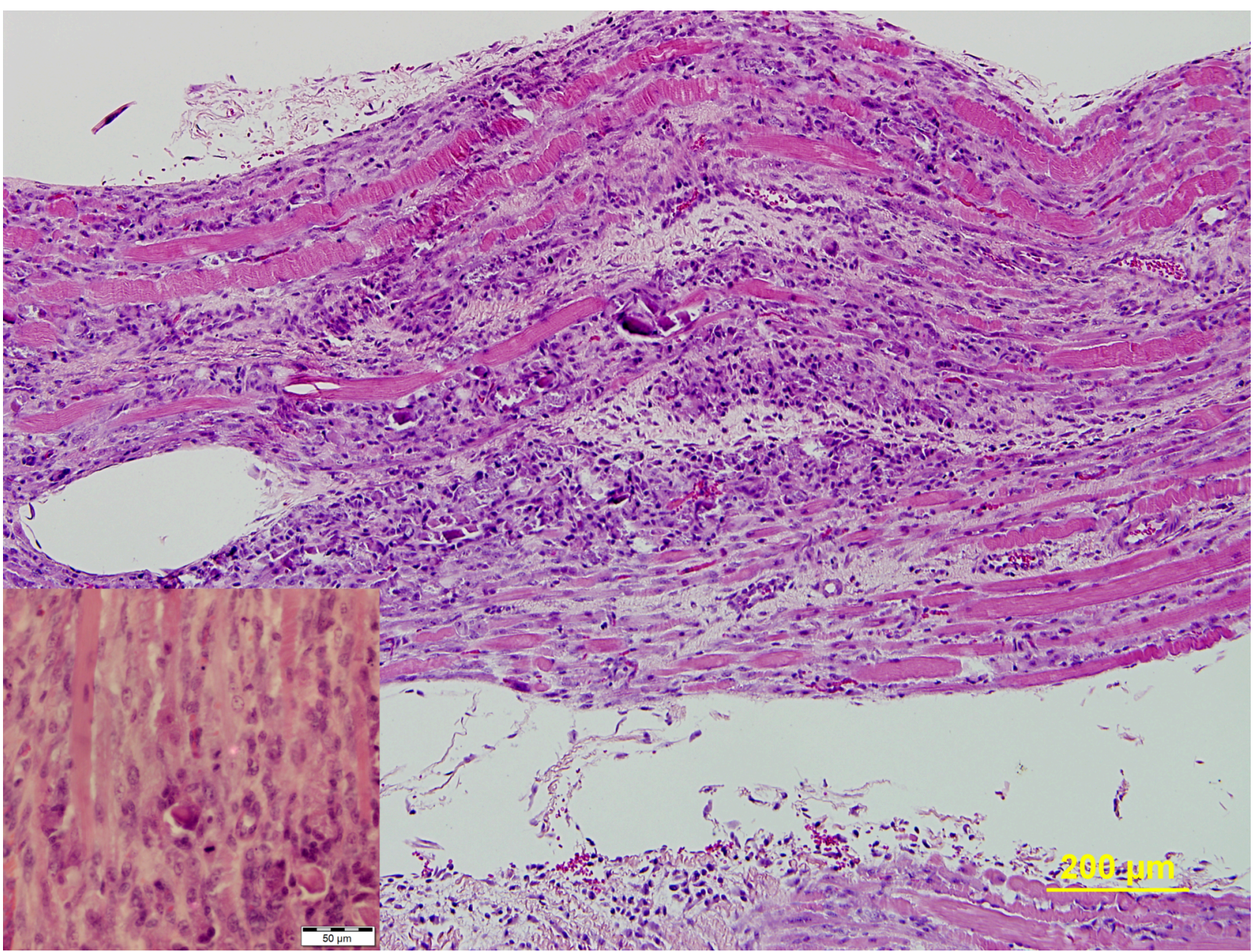

AVJ_12877_Figure 4_edit.tif 


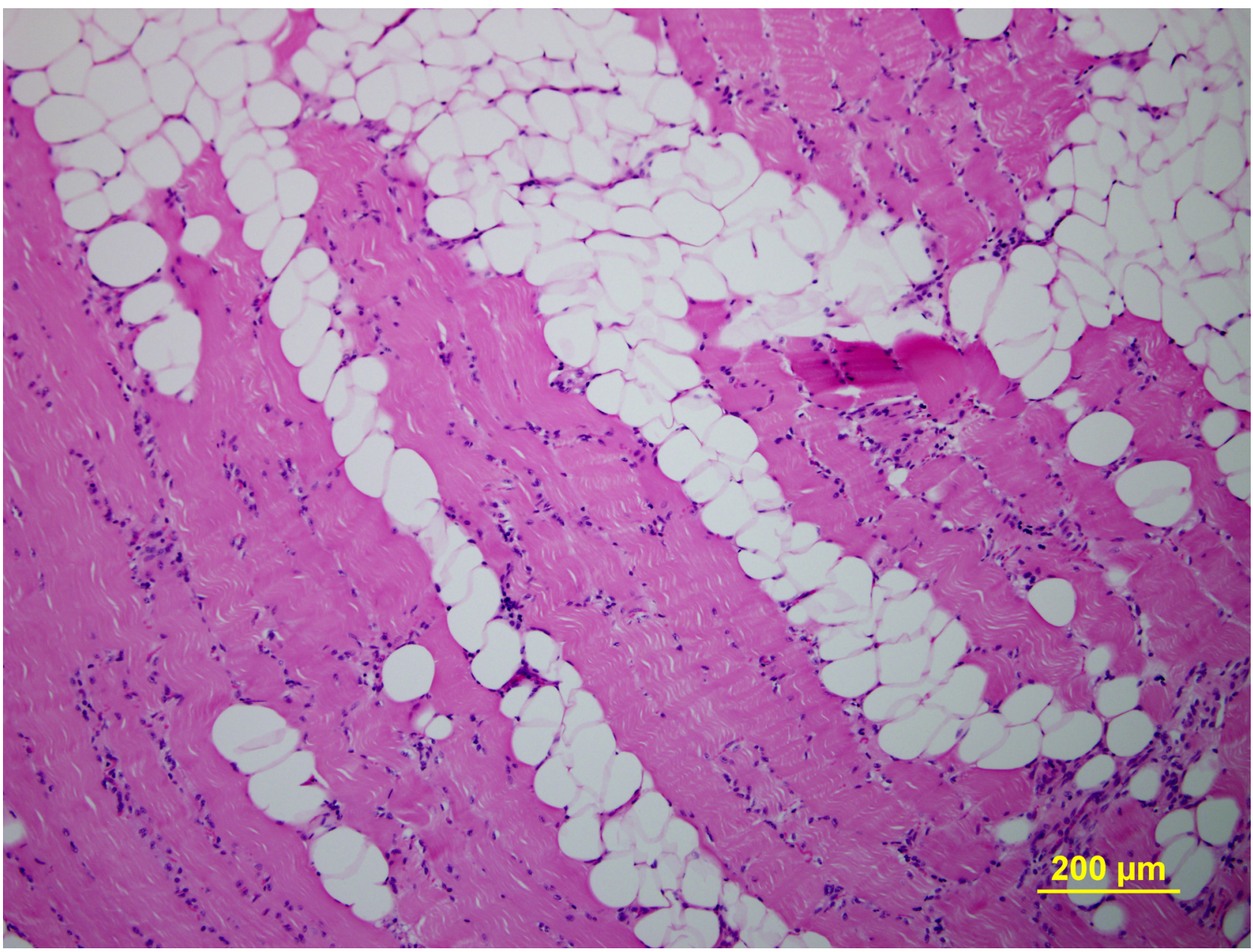

AVJ_12877_Figure 5_edit.jpg 


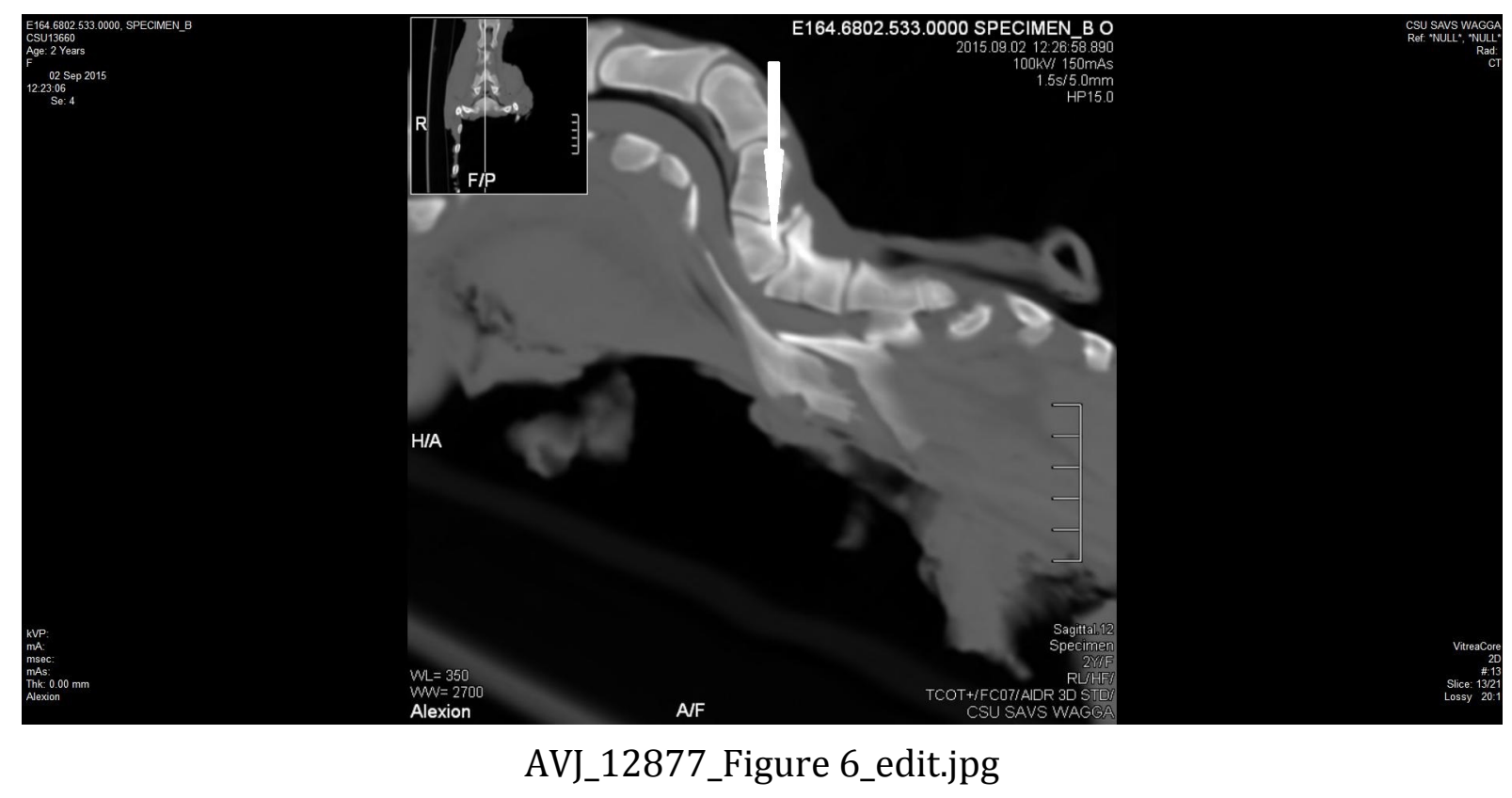

This article is protected by copyright. All rights reserved. 